\title{
Arginine methylation facilitates the nuclear export of hnRNP proteins
}

\author{
Elisa C. Shen, Michael F. Henry, ${ }^{1}$ Valerie H. Weiss, Sandro R. Valentini, Pamela A. Silver, ${ }^{2}$ \\ and Margaret S. Lee
}

Department of Biological Chemistry and Molecular Pharmacology, Harvard M edical School, and Dana Farber Cancer Institute, Boston, M assachusetts 02115 USA

\begin{abstract}
Eukaryotic mRNA processing and export is mediated by various heterogeneous nuclear ribonucleoproteins (hnRNPS). Many of these hnRNPs are methylated on arginine residues. In the yeast, Saccharomyces cerevisiae, the predominant enzyme responsible for arginine methylation is Hmtlp. Hmtlp methylates both Npl 3p and Hrplp, which are shuttling hnRNPs involved in mRNA processing and export. Here, we employ an in vivo nuclear export assay to show that arginine methylation is important for the nuclear export of these hnRNPs. Both Npl3p and Hrplp fail to exit the nucleus in cells lacking Hmtlp, and overexpression of Hmtlp enhances Npl 3p export. The export of a novel hnRNP-like protein, Hrblp, which does not bind poly(A) ${ }^{+}$RNA, however, is not affected by the lack of methylation. Furthermore, we find a genetic relationship between Hmtlp and cap-binding protein 80 (C BP80). Together, these findings establish that one biological role for arginine methylation is in facilitating the export of certain hnRNPs out of the nucleus.
\end{abstract}

[Key Words: HMT 1; N PL3; HRP1; CBP80; heterogeneous ribonucleoprotein (hnRNP); argi nine methylation; mRN A export]

Received N ovember 21, 1997; revised version accepted January 12, 1998.

While in the nucleus, mRNA precursors, referred to as pre-mRNAs or heterogeneous nuclear RN As (hnRNAs), undergo a series of processing events before traveling to the cytopl asm. These maturation events include capping at the $5^{\prime}$ end, splicing, and 3 '-end cleavage followed by polyadenylation. From the time they leave the transcription complex, hnRNAs are associated with proteins, some of which have been proposed to be mediators of RNA export (for review, see Lee and Silver 1997). The set of proteins that bind hnRNAs, with the exception of small nuclear RNPs, are referred to as heterogeneous nuclear ribonucleoproteins (hnRNPs).

Among the most abundant proteins in the nucleus (Kiledjian et al. 1994), there are over 20 mammalian hnRNPs, proposed to function in nearly every step of mRN A maturation including export (Piñol-Roma 1997). One of the best-studied hnRNPs, hnRNP A1, travels back and forth between the nucl eus and the cytopl asm in a process termed nucleocytoplasmic shuttling (PiñolRoma and Dreyfuss 1992). In addition, an hnRNP A1like protein in the insect Chironomus tentans can be seen by immunoelectron microscopy to be associated with pre-mRNA traveling through the nuclear pore to the cytoplasm (Visa et al. 1996a).

\footnotetext{
IPresent address: Department of Molecular Biology, University of Medicine and Dentistry of New Jersey, Stratford, New Jersey 08084 USA. ${ }^{2}$ Corresponding author.

E-MAIL pamela_ilver@dfci.harvard.edu; FAX (617) 632-5103.
}

The discovery of a nuclear export signal (NES) in some hnRN Ps has suggested further that these hnRN Ps could play an active role in RN A export. A 38-amino-acid sequence within hnRN P A 1 termed M 9 has been found to be necessary and sufficient for export of the protein to the cytoplasm (Michael et al. 1995). Microinjection experiments have shown that saturating amounts of the M9 domain block mRNA export in Xenopus oocytes (Izaurral de et al. 1997). A model for mRNA export has been proposed in which the export signals on the shuttling hnRN Ps are directly responsible for the translocation of bound mRNAs into the cytoplasm (Fischer et al. 1996; Nigg 1997). This model is best supported by studies of the HIV Rev protein. Through its leucine-rich NES, Rev facilitates the nuclear export of partially spliced and unspliced viral RNAs containing the Rev response element (Fischer et al. 1996).

Further evidence for the involvement of hnRN Ps in mRN A export comes from studies in the yeast Saccharomyces cerevisiae. N pl $3 p$ is a yeast hnRNP (Bossi eet al. 1992; Russell and Tollervey 1992) with structural features similar to those found in some mammalian hnRNPs, such as hnRNP A1. These include two RNPtype RN A-recognition motifs (RRM s), and a glycine-rich domain in the form of 15 arginine-glycine-glycine (RGG) repeats (Birney et al. 1993). Although N pl3p appears to local ize to the nucleus in a distinct non-nucl eolar pattern similar to human hnRN Ps (Flach et al. 1994), it actually shuttles between the nucleus and the cyto- 
plasm (Flach et al. 1994; Lee et al. 1996). Strains bearing mutant al leles of NPL3 accumulate poly(A) ${ }^{+}$RN A in the nucleus (Russell and Tollervey 1992; Singleton et al. 1995; Henry et al. 1996; Lee et al. 1996). Export of these mutant $\mathrm{N}$ pl $3 p$ proteins from the nucleus is also defective, providing further evidence that $\mathrm{N} \mathrm{pl3p}$ is a poly(A $)^{+}$ RNA carrier (Lee et al. 1996). Moreover, Npl3p export depends on ongoing RNA polymerase II transcription, suggesting a tight association between the export of poly $(A)^{+}$RNA and N pl 3p (Lee et al. 1996).

A second yeast hnRNP, HRP1, was identified in a screen for suppressors of the temperature-sensitive mutant, npl3-1 (Henry et al. 1996). This essential gene encodes a protein with two RN A-recognition motifs most similar to those found in human hnRNPs A1, A2/B1, and D/AUF1. In addition, the carboxyl terminus of the protein is arginine and glycine rich. Hrplp has recently been shown to be required for proper 3 ' end formation in S. cerevisiae (Kessler et al. 1997). As such, it binds mRNA at the UA-rich efficiency element, which is required for both cleavage and polyadenylation. Although Hrplp local izes to the nucleus at steady state, it has also been found to efficiently exit the nucleus (Kessler et al. 1997). These data suggest a link between polyadenylation and mRNA export in yeast.

It has become increasingly apparent that hnRN Ps play key regulatory roles at all levels of RN A processing (for review, see Dreyfuss et al. 1993). Such regulation may be mediated by post-translational modifications of the hnRN Ps themselves. In fact, most hnRN Ps do undergo such modifications including phosphorylation (e.g., Cobianchi et al. 1993; Piñol-Roma and Dreyfuss 1993), glycosylation (Soulard et al. 1993), and methylation (e.g., Liu and Dreyfuss 1995). Partially purified mammalian hnRNP complexes contain proteins with a high level of the unusually modified amino acid $N^{G}, N^{G}$-dimethylarginine (Beyer et al . 1977). In fact, hnRN Ps contain about $65 \%$ of methylated arginines in the cell nucleus (Boffa et al. 1977), indicating that the methylation state of these proteins is likely to have an important effect on their functions. In addition, these methylated arginine residues are found in other non-hnRN P RN A-binding proteins, all of which appear to contain RGG repeats ( $\mathrm{N}$ ajbauer et al. 1993 and references therein). Despite speculation that methylation affects the RNA-binding activity of hnRN Ps (Rajpurohit et al. 1994), or the interactions of hnRN Ps with other proteins (Liu and Dreyfuss 1995), no in vivo function has been defined.

The recent identification of the enzymes responsible for arginine methylation provides an important gateway to further our understanding of its true biological role. Protein arginine methyltransferases specific for hnRN P A1 have been partially purified from several sources (Ghosh et al. 1988; Rawal et al. 1994; Liu and Dreyfuss 1995). The cDNAs encoding human and rat arginine methyltransferases have been identified (Lin et al. 1996; N ikawa et al. 1996; Katsanis et al . 1997). In S. cerevisiae, a homolog of the rat protein arginine methyltransferase (PRMT1) termed HMT1/RMT1 has been identified in a synthetic lethal screen with the temperature-sensitive mutant, npl3-1 (Henry and Silver 1996). HMT1/RMT1 was independently identified as a gene whose protein product represents the major arginine methyltransferase activity present in S. cerevisiae (Gary et al. 1996). Hmtlp has been shown to methylate $\mathrm{N}$ pl $3 p$ both in vitro and in vivo (Henry and Silver 1996; Siebel and Guthrie 1996), and to local ize to the nucl eus (Henry and Silver 1996). In a strain containing a null allele of HMT1, methylation of $\mathrm{N} \mathrm{pl3p}$ is no longer detectable (Henry and Silver 1996). Taken together, these data suggest that Hmtlp may play a role in the regulation of $\mathrm{N} \mathrm{pl3p}$ function.

In this investigation, we show that, like N pl3p, Hrplp is methylated by Hmtlp. More importantly, we demonstrate that, in the absence of Hmtlp methylation, the ability of $\mathrm{N} \mathrm{pl3p}$ and Hrplp to exit the nucleus is impaired. This study is the first in vivo demonstration of a function for hnRN P arginine methylation and implicates this modification as part of the mechanism by which protein-RNA complexes are recognized for nuclear export.

\section{Results}

Effect of methylation on the nuclear export of mRNA-binding proteins

We have shown previously that both $\mathrm{N} \mathrm{pl3p}$ and Hrplp exit the nucleus (Flach et al. 1994; Lee et al. 1996; Kessler et al. 1997). To test whether methylation of $\mathrm{N} \mathrm{pl3p}$ and Hrplp has an effect on their export, we utilized a nuclear export assay (Lee et al. 1996). This assay exploits the properties of a temperature-sensitive mutant of the nucl eoporin N up49p (Doye et al. 1994). At the nonpermissive temperature of $36.5^{\circ} \mathrm{C}$, import of proteins into the nucleus is blocked in the nup49-313 strain, whereas nuclear export is not appreciably affected. Because of this phenotype, shuttling proteins accumulate in the cytopl asm after exit from the nucl eus. To monitor this export visually, the green fluorescent protein (GFP) is fused to the protein of interest and placed under a galactose inducible (GAL1) promoter. After induction, cells are either shifted to the nonpermissive temperature or maintained at the permissive temperature of $25^{\circ} \mathrm{C}$.

The deletion of HMT1 alone results in no poly $(A)^{+}$ RNA export defects or nuclear protein mislocalization (Henry and Silver 1996). To study the effect of methylation through the use of this export assay, a strain containing the nup49-313 mutation and a deletion of the HMT1 gene was constructed (see M aterials and M ethods).

To monitor the localization of N pl 3p, GFP was fused to its amino terminus, and the resulting fusion protein was placed under the GAL1 promoter (Lee et al. 1996). GFP-N pl 3p accurately reflects the behavior of its endogenous counterpart (Lee et al. 1996) under all conditions examined. The nuclear export assay was performed in the nup49-313 $\Delta \mathrm{HMT} 1$ strain, as well as the nup49-313 strain. At the permissive temperature, GFP-N pl 3p localizes entirely in the nucleus in both strains (Fig. $1 \mathrm{~B}, \mathrm{~F}$ ). Athough GFP-N pl3p accumulates in the cytoplasm of 


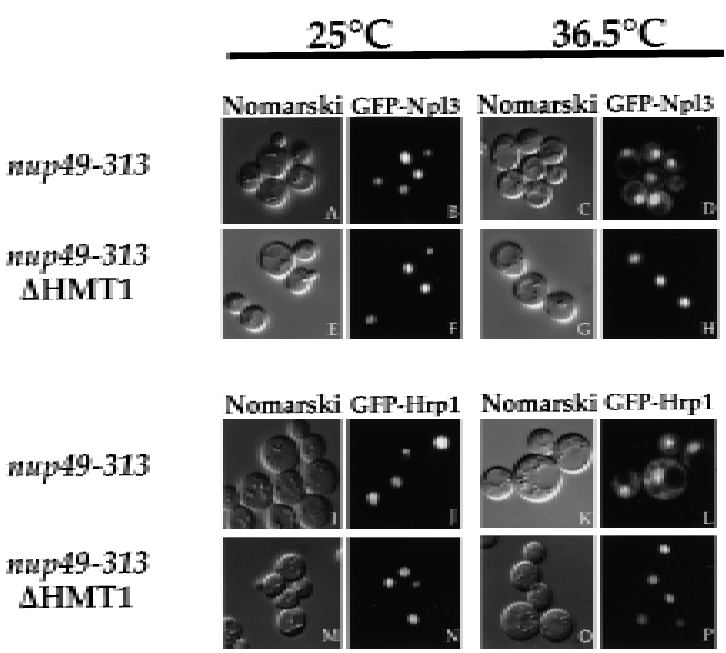

Figure 1. Export of $\mathrm{N} \mathrm{pl} \mathrm{3p} \mathrm{and} \mathrm{Hrplp}$ is blocked in the absence of Hmtlp. Either nup49-313 cells (A-D and I-L) or the nup49313 strain in which HMT1 has been del eted (E-H and M-P) were incubated in the export assay. The reporter used was GFP$\mathrm{N}$ pl3p (pPS811; A-H) or GFP-Hrplp (pPS1358; I-P). Cells were incubated at $25^{\circ} \mathrm{C}(\mathrm{A}, \mathrm{B}, \mathrm{E}, \mathrm{F}, \mathrm{I}, \mathrm{J}, \mathrm{M}, \mathrm{N})$ or at $36.5^{\circ} \mathrm{C}(\mathrm{C}, \mathrm{D}, \mathrm{G}, \mathrm{H}, \mathrm{K}$, $L, O, P)$ for $5 \mathrm{hr}$. Cells were photographed by use of $\mathrm{N}$ omarski optics (A,C,E,G,I,K,M,$O$ ) or for GFP fluorescence (B,D,F, $\mathrm{H}, J, L, N, P)$.

the nup49-313 cells at $36.5^{\circ} \mathrm{C}$ (Fig. 1D), the signal remains completely nuclear in the nup49-313 $\Delta \mathrm{HMT} 1$ cells (Fig. $1 \mathrm{H}$ ). As in the $\Delta \mathrm{HMT} 1$ strain (Henry and Silver 1996), N pl3p is no longer methylated in the double mutant (data not shown). These results indicate that the export of $\mathrm{N} \mathrm{pl} 3 p$ out of the nucleus is affected by methylation.

To determine whether this effect extended to another shuttling hnRN P, Hrplp (Henry et al. 1996; Kessler et al. 1997), the nuclear export assay was performed using GFP-Hrplp as the reporter protein. The local ization patterns observed for GFP-Hrplp paralleled those seen previously with myc-Hrplp (Henry et al. 1996), and the fusion protein has been shown to be functional (Kessler et al. 1997). When the cells were incubated at $25^{\circ} \mathrm{C}$, GFP-Hrplp was seen in the nucleus in both strains (Fig. 1],N). As shown in our previous study (Kessler et al. 1997), GFP-Hrplp accumulated in the cytoplasm in nup49-313 cells (Fig. 1L) following shift to $36.5^{\circ} \mathrm{C}$. Conversely, the fusion protein failed to leave the nucleus in the nup49-313 $\Delta$ HMT1 strain (Fig. 1P). These results demonstrate that nuclear export of Hrplp, like that of $\mathrm{N} \mathrm{pl3p}$, is affected by methylation. The failure of GFPHrplp and GFP-N pl $3 p$ to leave the nucleus at the restrictive temperature may be attributable to a slower rate of export in the strain lacking Hmtlp.

\section{Hrplp is methylated by Hmtlp}

Previous work has shown that $\mathrm{Hmtlp}$ is required for $\mathrm{N} \mathrm{pl} 3 \mathrm{p}$ methylation and that this methylation occurs in the RGG-containing carboxyl terminus (Henry and Sil- ver 1996; Siebel and Guthrie 1996). Because HRP1 was originally identified because of its genetic interactions with NPL3 and the encoded protein (Hrplp) contains three RGGs, we tested whether Hmtlp was able to methylate Hrplp as well. Recombinant Hmtlp and Hrplp, both purified from Escherichia coli, were incubated with [methyl ${ }^{3} \mathrm{H}$ ]-S-adenosylmethionine ([meth$\mathrm{yl}^{3} \mathrm{H}$-SAM; see Materials and Methods). The proteins were resolved by SDS-PAGE and labeling was detected by fluorography. Under these conditions, Hrplp is methylated by Hmtlp (Fig. 2A, lane 2). In addition, the assay was repeated with $\mathrm{N}$ pl 3p purified from $\mathrm{E}$. coli (Fig. 2A, Iane 1). Quantitation of the incorporated label indicates that $\mathrm{Npl} 3 \mathrm{p}$ is methylated approximately sixfold more than as Hrplp. When the assay was performed in the absence of Hmtlp, no labeling of $\mathrm{N}$ pl 3p or Hrplp was detected (Fig. 2A, lanes 5,6).

Methylation is not required for the export of all hnRNPs

The novel hnRNP, HRB1 (TOM34, YNL004w; Philippsen et al. 1997), was identified during the course of a screen for chromosomal mutations that are lethal in combination with a deletion of the nonessential nucleoporin NU P2. HRB1 was cl oned as a very weak suppressor of the synthetically lethal combination of $\triangle N U P 2$ and a currently unknown mutant (M.S. Lee and P.A. Silver, unpubl.). The protein contains three RRMs, and an amino-terminal domain that contains two repeats of the tripeptide RGG. HRB1 is not essential for vegetative growth (see $M$ aterials and M ethods).

To examine the subcellular localization of Hrblp, an epitope-tagged version of this protein was generated with a single myc epitope fused to the carboxyl terminus of the protein. Tagged and untagged versions of Hrblp un-

A

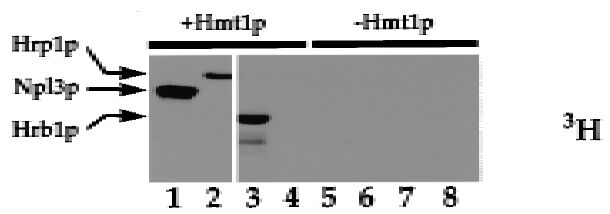

B

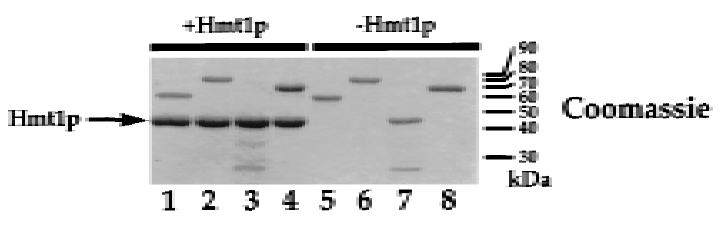

Figure 2. N pl3p, Hrplp and Hrblp are methylated by Hmtlp. Recombinant substrates N pl3p (lanes 1,5), Hrplp (lanes 2,6), Hrblp (lanes 3,7) were purified from E. coli and BSA was used as a negative control (lanes 4,8). Substrates were incubated with [methyl ${ }^{3} \mathrm{H}$ ]-SAM in the presence (lanes 1-4) or absence (lanes 5-8) of Hmtlp purified from E. coli. Samples were resolved by SDS-PAGE. Proteins were detected by Coomassie staining (B) and labeling was detected by fluorography (A). Protein molecular weights are indicated in kilodaltons. 
der the control of the inducible GAL1 promoter were constructed and harbored in a strain lacking the chromosomal copy of HRB1. Indirect immunofluorescence microscopy performed on these cells with the anti-M yc monoclonal 9E10 indicates that Hrblp-M yc is located primarily in the nucleus (Fig. 3I). This is similar to the localization of $\mathrm{N} \mathrm{pl3-M} \mathrm{yc} \mathrm{(Fig.} \mathrm{3C).} \mathrm{Virtually} \mathrm{no} \mathrm{staining}$ is observed in cells containing $\mathrm{Hrblp}$ lacking the epi tope tag (Fig. 3F). Nuclear Hrblp-Myc is also seen with a centromeric plasmid containing HRB1 under its own promoter, although the signal is weaker (data not shown).

To examine whether Hrblp exits the nucleus, the nuclear export assay was performed with a GFP-Hrblp fusion (Fig. 4). The localization of GFP-Hrblp was first examined in a wild-type strain. After induction of the fusion protein and incubation at either $25^{\circ} \mathrm{C}$ or $36.5^{\circ} \mathrm{C}$, GFP-Hrblp is found predominantly in the nucleus with some fai nt cytoplasmic signal (Fig. 4B,D). The same predominantly nuclear localization is seen when the nup49313 strain containing this reporter is induced followed by incubation at $25^{\circ} \mathrm{C}$ (Fig. 4F). When nup49-313 cells are induced followed by a shift to $36.5^{\circ} \mathrm{C}$, however, GFPHrblp accumulates in the cytoplasm, indicating export from the nucleus (Fig. 4H). Furthermore, GFP-Hrblp is still capable of export from the nucleus in a nup49-313 strain lacking HMT1 (Fig. 4L). These results indicate that although Hrblp is located primarily in the nucleus, its Iocalization represents a dynamic state within the cell. In addition, in contrast to the situation found with Hrplp and N pl3p, the absence of functional Hmtlp has no effect on the ability of Hrblp to exit the nucleus.

Hrblp is methylated by Hmtlp

Because Hrblp contains RGG repeats, we tested whether this protein is also methylated by Hmtlp. Recombinant

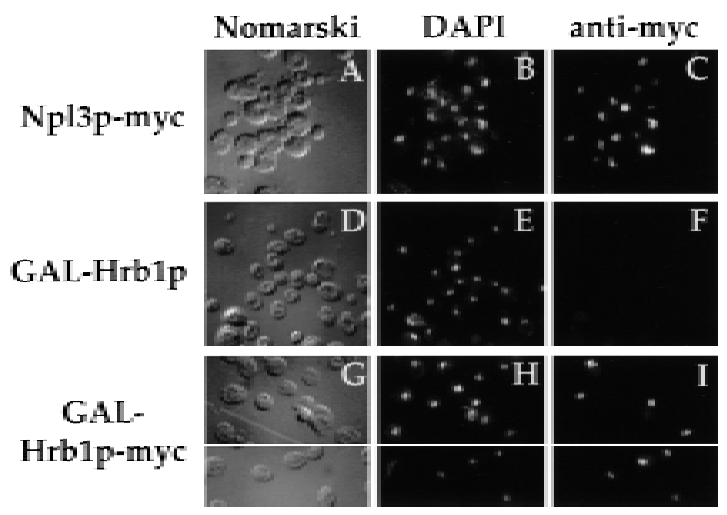

Figure 3. Hrblp is a novel nuclear hnRNP. Cells harboring plasmids expressing $\mathrm{N} \mathrm{pl} \mathrm{3p-M} \mathrm{yc} \mathrm{expressed} \mathrm{from} \mathrm{its} \mathrm{endogenous}$ promoter $(\mathrm{A}-\mathrm{C})$, or Hrblp $(\mathrm{D}-\mathrm{F})$ and Hrblp-Myc $(\mathrm{G}-\mathrm{I})$ under control of the inducible GAL1 promoter were subjected to immunofluorescence microscopy with the $9 \mathrm{E} 10$ monoclonal antibody. The Myc-tagged proteins were visualized with FITC Iabeled anti-mouse antibody (C,F,I). DNA was visualized using DAPI $(B, E, H)$. Cells were photographed by use of $N$ omarski op$\operatorname{tics}(A, D, G)$.
Hrblp was purified from E. coli and incubated with [methyl ${ }^{3} \mathrm{H}$ ]-SAM in the presence or absence of bacterially produced Hmtlp (Fig. 2). Reaction products were separated by SDS-PAGE, and labeling was detected by fluorography. In the presence of Hmtlp, Hrblp is methylated (Fig. 2A, lane 3). When Hmtlp is omitted from the reaction, no labeling of Hrblp is seen (Fig. 2A, lane 7). $\mathrm{N}$ ote that in the autoradiograph in Figure 2A, lanes 3-8 were exposed eight times longer than Figure $2 \mathrm{~A}$, lanes 1 and 2, al though equal amounts of substrate protein were present in each reaction (Fig. 2B). Quantitation of the amount of radioactivity incorporated into the individual substrate in each reaction indicates that $\mathrm{N} \mathrm{pl3p}$ contains 26 times as much label as Hrblp. Similarly, Hrplp contains 4.5 times as much label as Hrblp.

\section{Nuclear protein export and RNA synthesis}

Because the nuclear export of $\mathrm{N} \mathrm{pl3p}$ requires ongoing RNA synthesis, we tested whether the same is true for Hrplp and Hrblp. To accomplish this, we employed a temperature-sensitive al lele of RNA Pol II termed rpb1-1 (N onet et al. 1987). In the rpb1-1 strain, RN A Pol II transcription is inhibited at the nonpermissive temperature. The nuclear export assay was performed with a strain containing both the nup49-313 and rpb1-1 mutant alleles (Lee et al. 1996). Consistent with previous observations (Lee et al. 1996), GFP-N pl3p failed to exit the nucleus in this strain at the nonpermissive temperature (Fig. 5D). Furthermore, both GFP-Hrplp and GFP-Hrblp also failed to accumulate in the cytoplasm (Fig. 5, $\mathrm{H}$ and $L$, respectively) at the nonpermissive temperature. This result is not attributable to a lack of protein synthesis because, when the assay was performed in the presence or absence of the protein synthesis inhibitor cycloheximide, GFP-Hrplp or GFP-H rblp accumulated in the cytoplasm at equal levels (data not shown). These results indicate that RN A Pol II transcription, but not new protein synthesis, is required for the export of Hrplp and Hrblp from the nucleus.

Both N pl 3p and Hrplp bind poly (A ) ${ }^{+}$RN A (Wilson et al. 1994; Kessler et al. 1997). Hrblp was also examined for its ability to bind to poly $(A)^{+}$RNA by irradiation of cells with ultraviol et light to crosslink RN A to proteins. $\operatorname{Poly}(A)^{+}$RNA was then isolated from these cells and analyzed by Western blotting for the presence of $\mathrm{M}$ yctagged proteins. Hrblp was not detected in the poly(A $)^{+}$ RNA fraction when expressed either from its own promoter or from the high expression GAL1 promoter under conditions in which $\mathrm{N}$ pl $3 p$ was readily detectable (data not shown).

\section{Suppression of export defects by HMT1}

We previously generated and characterized a temperature-sensitive allele of NPL3, npl3-17 (Lee et al. 1996). This mutant displays a fully recessive phenotype that includes accumulation of poly $(A)^{+}$RN $A$ in the nucleus at the nonpermissive temperature. This al lele contains 

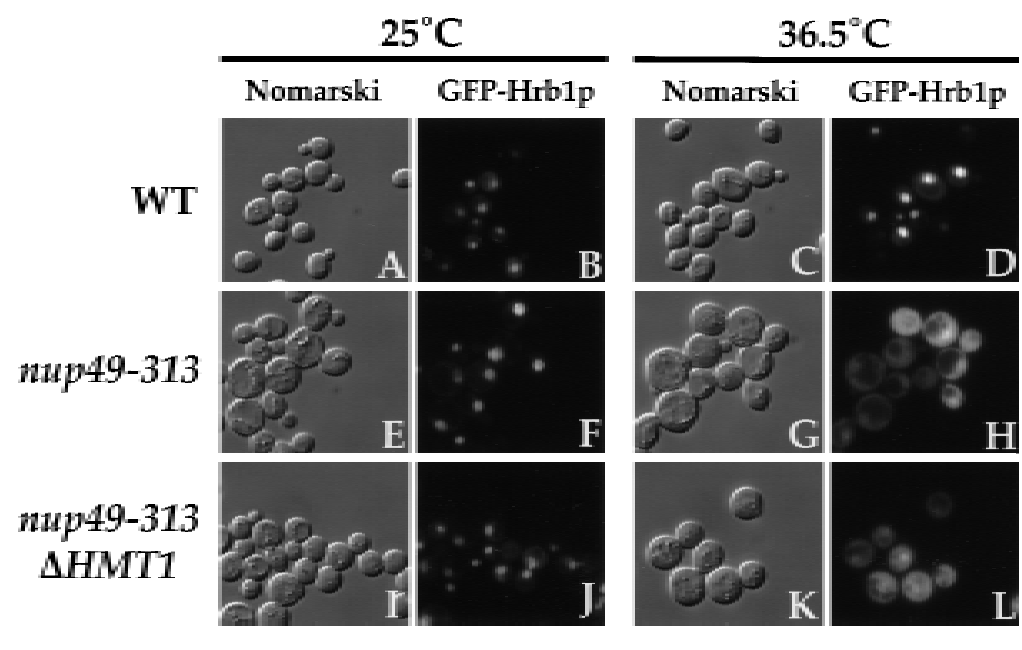

Figure 4. Hrblp export is unaffected by the absence of Hmtlp. Wild-type cells (A-D), nup49-313 cells (E-H), and nup49-313 $\Delta \mathrm{HMT1}$ double-mutant cells (I-L) containing the reporter plasmid pPS1341 expressing GFP-Hrblp were subjected to the export assay. Cells were incubated at $25^{\circ} \mathrm{C}(\mathrm{A}, \mathrm{B}, \mathrm{E}, \mathrm{F}, \mathrm{I}, \mathrm{J})$ or $36.5^{\circ} \mathrm{C}(C, D, G, H, K, L)$. Cells were photographed either using N omarski optics (A,C,E, G, I,K) or for the GFP signal $(B, D, F, H, J, L)$. two amino-acid substitutions, one in the first RRM, phenylalanine 160 changed to leucine ( $F 160 \mathrm{~L})$, and one in the second RRM, isoleucine 268 changed to threonine (I268T). Despite the presence of mutations in both RRMs, this protein can still be crosslinked to poly $(A)^{+}$ RNA in vivo (data not shown).

Overproduction of $\mathrm{Hmtlp}$ either on a high-copy plasmid (Fig. 6a), or by induction with the strong GAL1 promoter (data not shown) suppresses the temperature-sensitive growth defect of npl3-17 cells. The associated RNA export defect in npl3-17 is also suppressed by the overproduction of Hmtlp from a high-copy vector (data not shown) or with the GAL1 promoter (Fig. 6b, panel H), but not by the vector alone (Fig. $6 b$, panel D). We have shown previously that the single mutation in the first RRM, F160L, when present in the GFP-N pl 3p reporter protein (GFP-F160L) results in a mutant protein that is

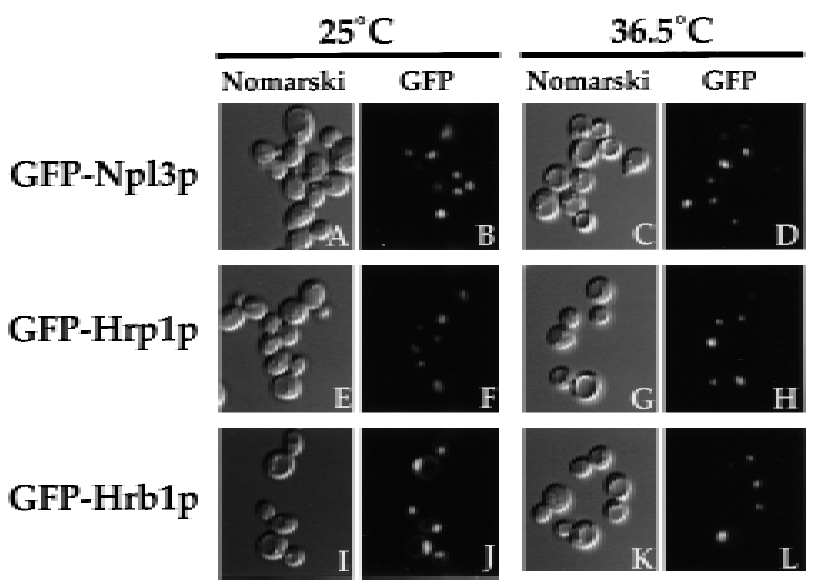

Figure 5. Export is blocked in the absence of RN A Pol II transcription. Double-mutant nup49-313 rpb1-1 cells carrying reporter plasmids expressing GFP-N pl3p (A-D), GFP-Hrplp (E$\mathrm{H})$, or GFP-Hrblp (I-L) were subjected to the export assay. Cells were incubated at $25^{\circ} \mathrm{C}(\mathrm{A}, \mathrm{B}, \mathrm{E}, \mathrm{F}, \mathrm{I}, \mathrm{J})$ or $36.5^{\circ} \mathrm{C}(\mathrm{C}, \mathrm{D}, \mathrm{G}, \mathrm{H}, \mathrm{K}, \mathrm{L})$ for $5 \mathrm{hr}$. Living cells were photographed by $\mathrm{Nomarski}$ optics $(A, C, E, G, I, K)$ or for the GFP signal $(B, D, F, H, J, L)$. defective in export from the nucleus (Lee et al. 1996). Taken together, these observations suggest the possibility that overproduction of $\mathrm{Hmt} 1 \mathrm{p}$ rescues the temperature-sensitive growth and RN A export defects of npl3-17 by restoring the ability of this mutant to exit the nucleus at the nonpermissive temperature.

To address this possibility, we constructed high-copy plasmids that carry HMT1 under its own promoter in addition to the GFP-N pl3p or GFP-F160L fusion proteins under control of the GAL1 promoter. We then compared the export of GFP-N pl3p and GFP-F160L in the nuclear export assay in the presence or absence of this additional plasmid-borne copy of HMT1 (Fig. 6c). As we have reported previously, there is often a nuclear GFP$\mathrm{N} \mathrm{pl3p}$ signal still visible at the time that export is examined in the assay (Lee et al. 1996; Fig. 6c, panel B), indicating that not all the $\mathrm{N} \mathrm{pl} 3 \mathrm{p}$ was exported during the course of this experiment. Interestingly, when HMT1 is included on the reporter plasmid, the accumulation of GFP-N pl3p in the cytoplasm is enhanced and most of the nuclear signal is gone (Fig. $6 c$, panel D). This result suggests that the methylation of $\mathrm{N} \mathrm{pl} 3 \mathrm{p}$ is limiting in this assay, possibly because of the high overexpression of the GFP-N pl 3p reporter in this system. Consistent with previous observations, the GFP-F160L reporter fails to accumulate in the cytoplasm after temperature shift in the export assay (Lee et al. 1996; Fig. 6c, panel F). The presence of HMT1 on the reporter plasmid, however, was able to rescue the defective export of GFP-F160L, resulting in accumulation of this reporter in the cytoplasm (Fig. 6c, panel H). These results indicate that overproduction of $\mathrm{Hmtl}$ p rescues the defective nucl ear export of the npl3-17 temperature-sensitive mutant.

\section{Synthetic lethality with HMT1}

Given the role of Hmtlp in the export of $\mathrm{Npl} 3 p$ and Hrplp from the nucleus, it is puzzling that HMT1 is not an essential gene. To identify genes that function in conjunction with Hmtlp in nuclear export, a synthetic lethal screen was conducted with a strain that contains a 
a
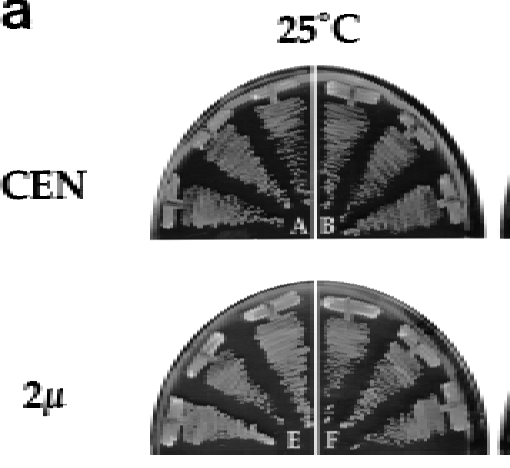
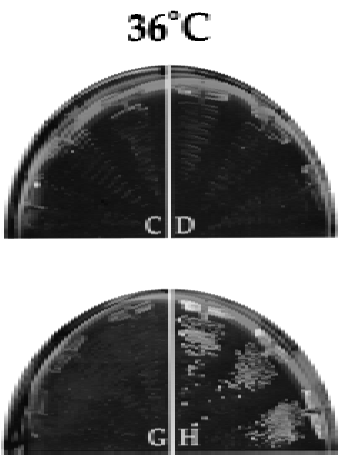

GAL

Vector

GAL

HMT1
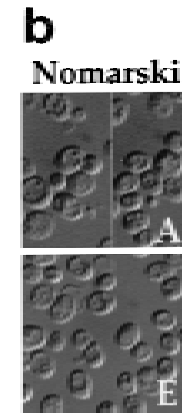
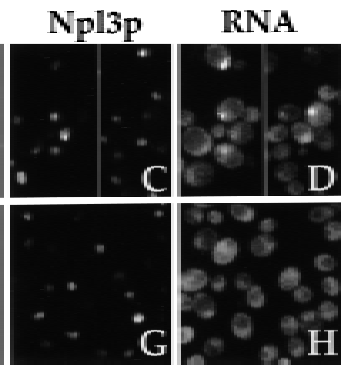

C

Figure 6. Overproduction of H mtlp rescues the export defects of npl3-17. (a) A npl3-17 strain was transformed with the following plasmids and streaked on synthetic complete plates lacking leucine and containing glucose as the carbon source: CEN vector alone (pRS315; panels A,C), CEN HMT1 (pPS1305; panels B,D), $2 \mu$ vector alone (YEp351; panels E,G), $2 \mu$ HMT1 (pPS1308; panels F,H). Plates were incubated at either $25^{\circ} \mathrm{C}$ (panels $A, B, E, F$ ) or $36^{\circ} \mathrm{C}$ (panels $C, D, G, H$ ) for 3 days. (b) npl3-17 cells harboring GAL1 vector pPS311 (panels A-D) or GAL1 HMT1 pPS1141 (panels E-H). Transformants were induced for protein expression for $2 \mathrm{hr}$ then incubated at $36^{\circ} \mathrm{C}$ for $4 \mathrm{hr}$, fixed with formal dehyde and processed for in situ hybridization and immunofluorescence microscopy to detect N pl3p (panels $C, G$ ) and poly $(A)^{+}$RN A (panels D, H). DNA was visualized by DAPI staining (panels B,F), and cells were photographed by use of N omarski optics (panels A,E). (c) nup49-313 cells containing GFP-N pl 3p (pPS811; panels A,B), GFP-N pl3p with HMT1 (pPS1348; panels C,D), GFP-F160L (pPS879; panels E,F), and GFPF160L with HMT1 (pPS1349; panels G,H) were subjected to the export assay. Cells shifted to $36.5^{\circ} \mathrm{C}$ for $5 \mathrm{hr}$ are shown. Cells were photographed by use of $\mathrm{N}$ omarski optics (panels $\mathrm{A}, \mathrm{C}, \mathrm{E}, \mathrm{G}$ ) and for the GFP signal (panels B,D,F,H).

deletion of the HMT1 gene and a wild-type copy of HMT1 on a U RA3 plasmid. This strain was mutagenized with ethyl methanesulfonate (EM S) to kill $\sim 50 \%$ of the cells. Cells containing mutations that are synthetically lethal with the HMT1 deletion were selected by the colony color assay (see Materials and M ethods). Following mutagenesis, only one recessive mutant was found to require the wild-type HMT1 gene for viability. The corresponding wild-type gene was cloned from a yeast genomic library by screening for restoration of the sectoring phenotype. Subcloning of complementing plasmids localized the minimal region required to a $4.2-\mathrm{kb}$ Clal DNA fragment. DNA sequence analysis and BLAST n searches revealed a single complete ORF that encodes the yeast homolog of the human cap-binding protein 80 (CBP80) (Izaurralde et al. 1994).

To establish linkage to the synthetic lethality, wildtype CBP80 was marked on the chromosome with the LEU 2 gene in a $\triangle$ HMT1 strain (see M aterials and M ethods). The resulting hapl oid was crossed to the synthetic lethal mutant strain. The diploid was sporulated, and tetrads were anal yzed. Each spore carried the null allele of HMT1. Assuming linkage, the spores that carried the LEU 2-marked wild-type copy of CBP80 would be able to lose the URA3 HMT1 plasmid. Those that carried the mutant form of CBP80 from the synthetic lethal strain, however, would require the plasmid to remain viable. To test for the ability to lose the plasmid, complete tetrads were streaked on plates containing 5-fluoro-orotic acid (5-FOA). The presence of 5-FOA in the plates selects against cells that carry the U RA 3 plasmid. Fourteen tetrads were analyzed, and all displayed the behavior predicted for linkage; two $\mathrm{Leu}^{+} \mathrm{FOA}^{\mathrm{R}}$ : two $\mathrm{leu}^{-} \mathrm{FOA}^{\mathrm{S}}$ spores.

Given that a mutant form of CBP80 is synthetically lethal with the deletion of $\triangle \mathrm{HMT1}$, we also tested whether the null allele of CBP80 would give the same result. It had been shown previously that CBP80 is a nonessential gene and that the del etion of CBP80 results in a slow growth phenotype (Uemera and Jigami 1992). We observed the same growth characteristics when constructing a null allele in our strain background (see $\mathrm{Ma}$ terials and $M$ ethods). A haploid containing the null allele of CBP80 was crossed to the $\triangle \mathrm{HMT} 1$ strain. The diploid was sporulated and tetrads were dissected. Of the 47 tetrads analyzed, no spore with the genotype of $\triangle \mathrm{CBP} 80$ $\triangle \mathrm{HMT} 1$ was found, indicating that the null alleles are also synthetically lethal. To verify this result, we introduced a copy of HMT1 on a URA3 plasmid into the $\triangle \mathrm{HMT} 1$ strain and crossed it to the $\triangle \mathrm{CBP} 80$. The dipl oid was sporulated, and tetrads were subjected to analysis. The presence of the plasmid rescued the synthetic lethality. In addition, when tetrads were streaked on FOA plates, the double mutant failed to grow, confirming our 
conclusion that $\triangle \mathrm{CBP} 80$ is synthetically lethal with $\Delta$ HMT1 (Fig. 7).

\section{Discussion}

In this report we have investigated the effect of arginine methylation on yeast hnRNPs. Previous studies have shown that the essential shuttling hnRNP, Npl3p, is modified by the arginine methyltransferase, $\mathrm{Hmtlp}$. We now demonstrate that $\mathrm{Hmtlp}$ is also able to methylate another essential shuttling hnRN P, Hrplp. By use of a nuclear export assay, the ability of $\mathrm{N} \mathrm{pl3p}$ and Hrplp to exit the nucleus was shown to depend on their methylation by Hmtlp. The export of a novel shuttling protein, Hrblp, however, is not impaired by lack of methylation. Taken together, these data indicate that methylation is critical for the export of certain proteins that bind mRNAs.

Our discovery of genetic interactions between HMT1 and NPL3, in combination with our data that $\mathrm{N} \mathrm{pl3p}$ is a substrate of $\mathrm{Hmtlp}$, provide the first insight into at least one biological role of arginine methylation. We have been able to study the effect of methylation on $\mathrm{N} \mathrm{pl3p}$ export by using a nuclear export assay that effectively uncouples export from reimport. Our resul ts suggest that the rate of export is decreased in a strain lacking HMT1. Under the conditions of our assay, $\mathrm{N} \mathrm{pl3p}$ does not leave the nucleus when HMT1 is absent, thereby indicating a role for methylation in its export. Because HMT1 is not an essential gene (Henry and Silver 1996), however, RN A export must still be occurring in vivo. One possibility is that when NPL3 is not methylated, it does not exit the nucleus, and its role in export is provided by another protein that does not require arginine methylation by Hmtlp. In our assay, GFP-N pl3p needs to reach a threshold level in the cytoplasm before it can be visually de-
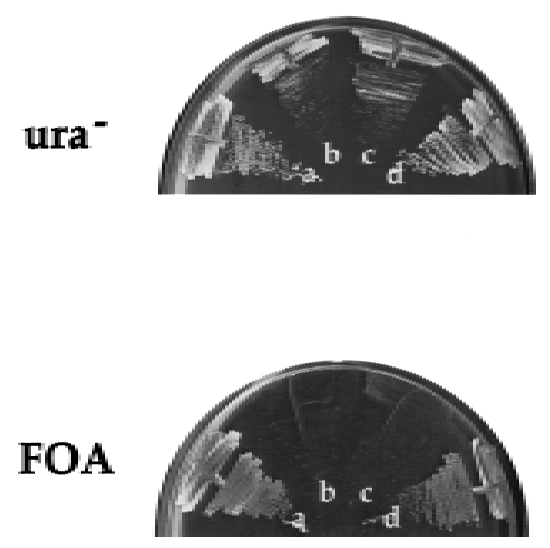

Figure 7. Deletion of both CBP80 and HMT1 is lethal. One tetrad from a cross of $\triangle \mathrm{HMT} 1$ covered with wild-type HMT1 and $\triangle C B P 80$ is shown. Two spores are wildtype for both alleles $(A, D)$, and two contain both del etion mutants $(B, C)$. Spores were streaked on synthetic complete media lacking uracil (top) or containing 5-FOA (bottom). Plates were incubated at $25^{\circ} \mathrm{C}$ for 2 days. tected. In a strain lacking HMT1, this threshold is not attained, suggesting that $\mathrm{N} \mathrm{pl} 3 \mathrm{p}$ is exiting the nucleus at a slower rate. Consistent with this idea, when the nuclear export assay was performed with cells overexpressing $\mathrm{Hmtlp}$, there was an increase in the cytoplasmic accumulation of GFP-N pl $3 p$ at the nonpermissive temperature (Fig. 6c, panel D). This result argues in favor of a role for methylation in the rate of export.

Is methylation affecting $\mathrm{Npl} 3 \mathrm{p}$ export directly or through its effects on another protein? We have shown previously that overexpression of $\mathrm{Hmtlp}$ can suppress the temperature-sensitive growth of certai n npl 3 mutant alleles (Henry and Silver 1996). In this study, we have found that overexpression of Hmtlp is able to suppress the temperature-sensitive growth and mRN A export defect associated with the npl3-17 mutant allele. Suppression of these defects correlates with the restoration of the ability of mutant $\mathrm{N} \mathrm{pl} 3$ to exit the nucleus. It is possible that the npl3-17 protein product is undermethylated in comparison to wild-type N pl3p. Hypermethylation by overproduction of Hmtlp could be enhancing the activity of a partially defective $\mathrm{N} \mathrm{pl} 3$ encoded by the mutant allele of NPL3. The suppression does not occur by bypassing the need for $\mathrm{N}$ pl $3 p$ because overexpression of Hmtlp is unable to suppress a null al lele of NPL3 (P. Chui and P.A. Silver, unpubl.). In sum, these data support the idea that methylation directly affects the export of $\mathrm{N} \mathrm{pl3p}$.

Interestingly, N pl3p is not the only protein whose export is affected by methylation. The export of another methyl ated mRNA-binding protein known to shuttle between the nucleus and the cytoplasm, Hrplp, is al so impaired when HMT1 is missing. Hrplp binds specifically to pre-mRNA and promotes its proper polyadenylation (Kessler et al. 1997). Furthermore, mutations in HRP1 can suppress mRNA export defects associated with certain npl3 temperature-sensitive alleles (Henry et al. 1996). It may be that, in addition to its role in polyadenylation, Hrplp acts together with Npl3p to promote mRN A export. M ethylation of Hrplp is not required for reconstitution of the cleavage and polyadenylation reactions (Kessler et al. 1997), suggesting further that this modification functions specifically in nuclear export. Thus, the efficient export of at least two shuttling hnRN Ps implicated in RNA processing and transport requires arginine methylation.

The idea that methylation by $\mathrm{Hmtl}$ phas a di rect effect on the export of $\mathrm{N} \mathrm{pl} \mathrm{3p} \mathrm{and} \mathrm{Hrplp} \mathrm{is} \mathrm{supported} \mathrm{by} \mathrm{our}$ studies of Hrblp. This novel hnRN P-like protein maintains its ability to exit the nucleus in the presence or absence of Hmtlp. One possibility is that although Hrblp is methylated in vitro, it may not be a bona fide substrate of Hmtlp in vivo. In addition, unlike Npl3p and Hrplp, we do not detect Hrblp bound to poly $(A)^{+}$ RNA. N evertheless, ongoing RN A Pol II transcription is required for nuclear export of Hrblp. One explanation for these results is that Hrblp binds a different Pol II transcript such as snRNAs. These results demonstrate that methylation does not affect the export of all shuttling proteins. Furthermore, the effect of methylation appears 
to be specific for at least two proteins that bind poly $(\mathrm{A})^{+}$ RNA.

There are several possibilities by which methylation could mediate an effect on a substrate. First, the modification could regulate protein-protein interactions. Methylation could lead to the formation and stabilization of an interaction or could disrupt a pre-existing interaction. Second, the modification could be involved in protein-RN A interactions (Cal nan et al. 1991; Rajpurohit et al. 1994). It has been proposed that arginine methylation could regulate the specificity of RNA binding (Calnan et al. 1991). Alternatively, arginine methylation could also play a role in protein stability. It has been shown that methylated hnRNP Al is more susceptible to trypsin digestion than its unmethylated counterpart (Rajpurohit et al. 1994). The stability of N pl3p, however, is unaffected in the absence of methylation (M .F. Henry and P.A. Silver, unpubl.). Finally, the presence of the $N^{G}$, $\mathrm{N}^{\mathrm{G}}$-dimethylarginine could help determine the localization of the modified protein (Pintucci et al . 1996) as demonstrated here. For instance, it could be mediating interactions of hnRN Ps with the nuclear export machinery (Ullman et al. 1997).

Given the effect of methylation by $\mathrm{Hmtlp}$ on the exit of $\mathrm{Npl} 3 \mathrm{p}$ and Hrplp from the nucleus, it is surprising that HMT1 is not an essential gene. However, we have discovered a situation where HMT1 is essential. In strains containing a mutant allele of the gene encoding CBP80, HMT1 is required for viability. Cbp80p and another protein termed Cbp20p form the cap-binding protein complex (CBC) (Izaurralde et al. 1994; Lewis et al. 1996). Cbp80p and Cbp20p have been isolated in yeast by both genetic and biochemical approaches (Uemera and Jigami 1992; Colot et al. 1996; Gorlich et al. 1996). Homologs of both proteins have been identified in other organisms, including amphibia and insects (Izaurral de et al. 1995; Visa et al. 1996b). Studies in Xenopus oocytes and HeLa cell extracts have shown that CBC mediates efficient pre-mRNA splicing, as well as snRNA export (for review, see Lewis and Izaurral de 1997). Studies of the association of Cbp20p with a specific hnRN P complex, the Balbiani ring particle in $C$. tentans, indicate that Cbp20p binds to nascent hnRNA very soon after transcription initiation and remains attached during translocation through the nuclear pore (Visa et al. 1996b). While the $5^{\prime}$-cap structure is not requi red for successful export, it has been shown to enhance the rate of mRNA export from the nucleus (Hamm and Mattaj 1990). Thus, the $\mathrm{CBC}$ is a good candidate for the role of the mediator of this effect.

How do Cbp80p, Hrplp, and N pl3p all affect the export of mRN A from the nucleus? From our genetic data, it is possible that $\mathrm{Cbp80p}, \mathrm{Hrplp}$, and $\mathrm{N} \mathrm{pl} 3 p$ all act in a linear pathway of export, with each step being affected by Hmtlp (Fig. 8A). As mentioned previously, a mutant allele of HRP1 is able to suppress a temperature-sensitive allele of NPL3. Suppression could occur by the ability of the mutant Hrplp to compensate for the defective $\mathrm{N} \mathrm{pl3p}$. In this scheme, methylation would play a role at the different levels of mRN A metabol ism including capping, polyadenylation, and export. First, Hmtlp has an effect on CBP80 function, as seen by the synthetic lethal interactions. Second, $\mathrm{Hmt} \mathrm{lp}$ interacts bi ochemically to modify Hrplp, a protein necessary for cleavage and polyadenylation. Finally, Hmtlp also modifies N pl3p, a potential carrier of mRNA out of the nucleus. Successful completion of each step, mediated by Hmtlp, could lead to efficient export of the mRNA.

A molecular model supported by the data is that proteins such as Cbp80p, N pl 3p, and Hrplp package the RNA for export, and that methylation plays a role in the efficiency of this packaging (Fig. 8B). All three factors are known to exit the nucleus and to bind pre-mRNAs (Flach et al. 1994; Gorlich et al. 1996; Lee et al. 1996; Kessler et al. 1997), thus supporting the possibility that they could be actively involved in export. The presence
A

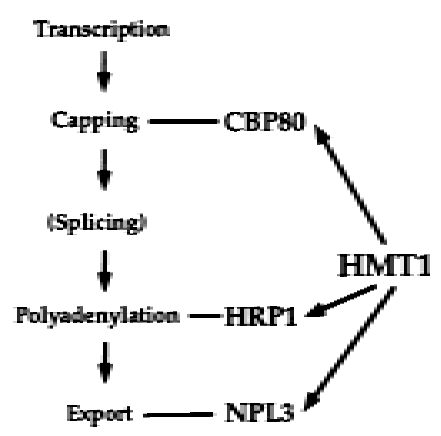

B

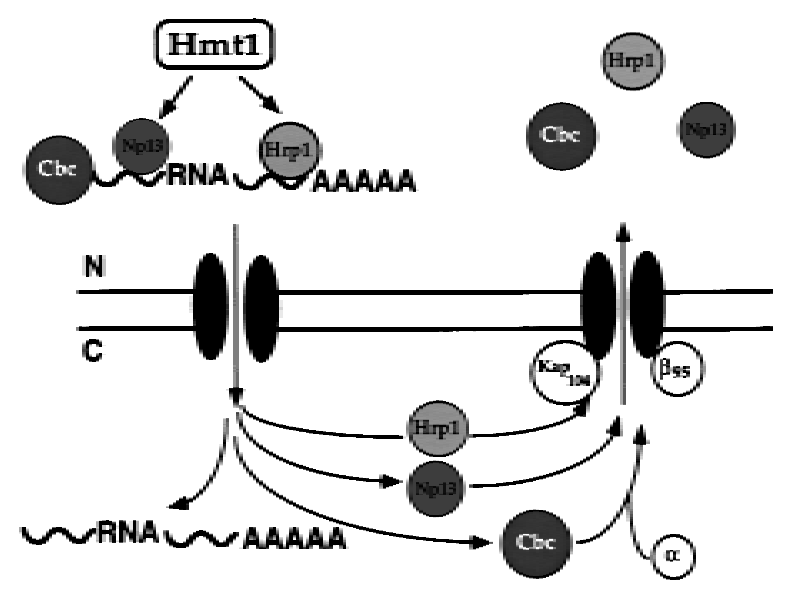

Figure 8. Models for HMT1 function in pre-mRNA metabolism, packaging, and export. (A) Genetic data suggest that HMT1 affects diverse functions in RN A metabolism including capping, polyadenylation, and export. (B) H mtlp methylates at least two nucl ear RN A binding proteins that play a role in the export of RNA, possibly providing a signal to facilitate association of properly packaged RN As with the export machinery. Once in the cytoplasm, RN A binding proteins are released and re-enter the nucleus. 
of proteins associated with capping and polyadenylation could lead to more efficient packaging and export of the RN A to the cytoplasm. Consistent with this concept, we have found that a null allele of CBP80 is synthetically lethal with a temperature-sensitive allele of NPL3 (E.C. Shen and P.A. Silver, unpubl.). In this case, the presence of one defective packaging protein would cause the cell to be sick but still viable. In the presence of more than one defective packaging protein, however, RNA export would be so impaired as to result in cell death.

In this packaging model, $\mathrm{Hmtlp}$ could affect the functions of these proposed carriers of mRNA in several ways. One possibility is that methylation of Hrplp and $\mathrm{N} \mathrm{pl3p}$ could be affecting the interaction of these factors with each other. In addition, the modification could mediate interactions between these proteins and Cbp80p, or other hnRN Ps that are presumably binding pre-mRNAs. Formation of the proper export complex would be crucial for efficient exit of mRNA out of the nucleus. Another possibility is that methylation mediates interactions of these factors with the export machinery such as the recently identified nuclear export receptor, Xpolp/Crmlp
(Adachi and Yanagida 1989; Fornerod et al. 1997; N eville et al . 1997; Ossareh-N azari et al. 1997; Stade et al. 1997). Modification by Hmtlp could also be mediating the specificity of RNA binding by Hrplp and Npl3p and hence formation of a functional transport unit. Lack of modification by $\mathrm{Hmtlp}$ could result in less efficient packaging of this transport unit, and lead to slower export of mRNA out of the nucleus.

Conservation of the players in the packaging model from yeast to mammals suggests that this model can be applied to higher eukaryotes. The knowledge that human arginine-methylated hnRNPs (Liu and Dreyfuss 1995) are involved in mRN A processing makes it likely that some are involved in the packaging of the RNA. N otably, some viruses exploit the cellular export machinery to facilitate the maturation of their RNAs. Finally, viral RNA-binding proteins such as the herpes simplex virus ICP27 protein are known to be argininemethylated (M ears and Rice 1996). We should be able to extend our new understanding of the biological role of $\mathrm{Hmt} l \mathrm{p}$ and argi nine methylation to virally infected cells and the design of possible therapeutics.

Table 1. Plasmids used in this study

\begin{tabular}{|c|c|c|}
\hline Plasmid & Features & Source \\
\hline pETHisHrpl & HisHRP1 in pET 15b & $\begin{array}{l}\text { M. Kessler and C. Moore } \\
\text { (Tufts Medical School, Boston, MA) }\end{array}$ \\
\hline pET 9c-N PL3 & NPL3 in pET9c & $\begin{array}{l}\text { A. Krainer and A. Mayeda } \\
\text { (Cold Spring Harbor Laboratory, } \\
\text { Cold Spring Harbor, NY) }\end{array}$ \\
\hline pPS293 & yeast URA3 $2 \mu$ GAL1 promoter expression vector & Lee et al. (1996) \\
\hline pPS311 & yeast CEN URA3 GAL1 promoter expression vector & Flach et al. (1994) \\
\hline pPS709 & yeast $2 \mu$ URA3 ADE3 & Koepp et al. (1996) \\
\hline pPS811 & yeast $2 \mu$ URA 3 GFP-N p13p under GAL1 promoter & Lee et al. (1996) \\
\hline pPS877 & np13-17 allele in pRS306 & Lee et al. (1996) \\
\hline pPS879 & yeast $2 \mu$ URA 3 GFP-F160L under GAL1 promoter & Lee et al. (1996) \\
\hline pPS892 & yeast $2 \mu$ URA 3 GAL1 GST fusion expression vector & Koepp et al. (1996) \\
\hline pPS1141 & HMT1 ORF in pPS311 & Henry and Silver (1996) \\
\hline pPS1303 & yeast $2 \mu$ URA3 GAL1 sGFP fusion expression vector & this study \\
\hline pPS1305 & 2.7-kb Xbal HMT1 fragment in pRS315 & Henry and Silver (1996) \\
\hline pPS1307 & 2.7-kb Xbal fragment containing HMT1 in pRS316 & Henry and Silver (1996) \\
\hline pPS1308 & 2.7-kb Xbal-HindlII HMTI fragment in YEp351 & Henry and Silver (1996) \\
\hline pPS1319 & N del-BamHI His HMT1 PCR fragment in PET 15b & this study \\
\hline pPS1320 & 1.8-kb BamHI-Avrll HRB1 fragment in pPS892 & this study \\
\hline pPS1321 & 1766-bp PCR product containing HRB1 in $\mathrm{pBSK}^{+}$ & this study \\
\hline pPS1323 & 2.3-kb Ball-Sall GST-HRB1 fragment in pGEX-4T-1 & this study \\
\hline pPS1324 & 12.5-kb genomic insert in YCp50 (original HRB1 clone) & this study \\
\hline pPS1325 & 3.6-kb Xhol HRB1 fragment from pPS1324 in pRS315 & this study \\
\hline pPS1327 & 2.6-kb Spel-A vrll HRB1 fragment in PRS315 & this study \\
\hline pPS1332 & 1.8-kb BamHI-A vrll HRB1 fragment in pPS293 & this study \\
\hline pPS1333 & 1.3-kb HRB1-myc PCR product in pPS1332 & this study \\
\hline pPS1340 & 1-kb BsaBI-Sall HRB1-myc fragment in pPS1327 & this study \\
\hline pPS1341 & 1.1-kb HRB1 PCR product in pPS1303 (HRB1-sGFP) & this study \\
\hline pPS1347 & 2.5-kb BamHI HMT1 fragment from pPS1307 in pPS709 & this study \\
\hline pPS1348 & 2.7-kb Xbal HMT1 fragment from pPS1307 in pPS811 & this study \\
\hline pPS1349 & 2.7-kb Xbal HMT1 fragment from pPS1307 in pPS879 & this study \\
\hline pPS1352 & $4.2-\mathrm{kb}$ Clal fragment containing CBP80 in pRS316 & this study \\
\hline pPS1353 & Pstl-Xhol CBP80 fragment from pPS1352 in pRS305 & this study \\
\hline pPS1356 & 3.5-kb Scal NLP3-myc fragment in pRS315 & this study \\
\hline pPS1357 & NPL3-myc in pET 9c-N p13 & this study \\
\hline pPS1358 & Hrpl fused to the carboxyl terminus of GFP (pCGF-1C-HRP1) & Kessler et al. (1997) \\
\hline
\end{tabular}




\section{Materials and methods}

Plasmids and strains

Plasmids used in this study are listed in Table 1 . Yeast strains used are listed in Table 2. The di pl oid JU 4-2xJR26-19B (gift from Ed Hurt, Biochimie-Zentrum Heidel berg, Germany) was used to generate wild-type haploids PSY 603 and PSY 609. The npl3-17 allele was integrated by homologous recombination. To create the nup49-313 $\Delta$ HMT1 double mutant, nup49-313 was mated to PSY 1122, a strain created exactly as described for PSY 865 (Henry and Silver 1996). A PCR strategy (Baudin et al. 1993) was employed to disrupt HRB1 in the wild-type strain PSY 615. After sporulation, all tetrads had four viable spores, indicating that HRB1 is not essential for vegetative growth. All other strain constructions are described under headings for individual experiments.

\section{Export assay}

The nuclear export assay was performed exactly as described (Lee et al. 1996). Briefly, cells containing various reporter plasmids are induced for $2 \mathrm{hr}$ in medium containing galactose to express the reporter followed by repression for $2 \mathrm{hr}$ in medium containing glucose. Cells are then incubated at $25^{\circ} \mathrm{C}$ or $36.5^{\circ} \mathrm{C}$ for $5 \mathrm{hr}$ and examined for GFP fluorescence.

Purification of recombinant proteins from E. coli

HisHmtl was purified from E. coli by binding to a charged nickel column (Pharmacia). Bound proteins were eluted with
$500 \mathrm{~mm} \mathrm{~N} \mathrm{aCl}, 50 \mathrm{~mm}$ EDTA and dialyzed against buffer B (20 $\mathrm{mm}$ MOPS at pH 7.2, $50 \mathrm{~mm} \mathrm{NaCl}, 2 \mathrm{~mm}$ EDTA, $5 \mathrm{~mm}$ DTT) containing $50 \mathrm{~mm}$ EDTA, then against buffer B. HisHrpl was purified from E. coli like HisHmtl except that eluted proteins were dialyzed against buffer $C$ ( $20 \mathrm{~mm}$ potassium phosphate at $\mathrm{pH} 7.4,50 \mathrm{~mm} \mathrm{KCl}, 0.2 \mathrm{~mm}$ EDTA, $5 \mathrm{~mm}$ DTT) containing 50 mM EDTA and then against buffer $\mathrm{C}$. HisHrpl was then bound to a SP Sepharose column (Pharmacia) equilibrated with buffer $\mathrm{C}$, and eluted with a step gradient of buffer C containing 250 $\mathrm{mm}, 500 \mathrm{~mm}$, and then $750 \mathrm{~mm} \mathrm{KCl}$. Proteins were then dialyzed into buffer D (20 mM Tris at pH $8.0,50 \mathrm{~mm} \mathrm{KCl}, 0.2 \mathrm{~mm}$ EDTA, 5 mм DTT). GST-Hrblp was purified from E. coli by affinity to gl utathione-sepharose (Pharmacia) and rel eased from GST by cleavage with thrombin (Sigma) in the presence of 20 mM glutathione. Free GST was removed by incubation with glutathione-agarose, and the remaining protein was dialyzed against methylation assay buffer ( $50 \mathrm{~mm}$ MOPS at pH 7.2, $2 \mathrm{~mm}$ EDTA, $300 \mathrm{~mm} \mathrm{NaCl}$ ). HisHmtlp, HisHrplp, and Hrblp were concentrated with a Centriprep-10 ultra centrifugation unit (A micon). N pl 3P-M yc was purified from $\mathrm{E}$. coli by cesium chloride gradient fractionation as described (Krainer et al. 1991) by monitoring fractions with the mouse monoclonal anti-c-M yc $9 \mathrm{E} 10$ antibody. Fractions containing N pl 3p-M yc were purified further by anion-exchange chromatography on a M ono-Q column (Pharmacia) and cation-exchange chromatography on a Mono-S column (Pharmacia).

Methylation assay

Methylation of recombinant proteins was performed as de-

Table 2. Yeast strains used in this study

\begin{tabular}{|c|c|c|}
\hline Strain & Genotype & Source \\
\hline FY23 & MATa ura3-52 leu2 $21 \operatorname{trp} 1 \Delta 63$ & $\begin{array}{l}\text { Fred Winston } \\
\text { (Harvard M edical } \\
\text { School, Boston, MA) }\end{array}$ \\
\hline nup49-313 & MAT $\alpha$ nup49::TRP1 ura3 leu2 his3 ade2 ade3 plus pUN 100-nup49 ${ }^{\text {ss }}$-LEU 2 & Doye et al. (1994) \\
\hline CH1305 & MATa ura3 leu2 his3 ade2 ade3 can1 & Kranz and Holm (1990) \\
\hline JU4-2 ×JR26-19B & MATa/ $\alpha$ ura3-52/-teu2-3/-his3/+his4/+trp1/+hys1-1/-ade2-1/-ade8/+can1-100/- & Ed Hurt \\
\hline PSY 603 & MAT $\alpha$ ura3-52 leu2-3 his4 trp1 lys1-1 ade2-1 ade8 can1-100 & this study \\
\hline PSY 609 & MAT $\alpha$ ura3-52 leu2-3 his3 lys1-1 ade2-1 ade8 can1-100 & this study \\
\hline PSY 615 & MATa/ $\alpha$ ura3-52/-leu2-3/-his3/-trp1/+lys-1/-ade2-1/-ade8/- & Henry et al. (1996) \\
\hline PSY 814 & MATa npl 3:: HIS3 ura3-52 leu2-3 his3 trp1 lys1-1 ade2-1 ade8 plus YCpN PL3-3 & Henry et al. (1996) \\
\hline PSY 865 & MAT $\alpha$ hmt1:: HIS3 ura3 leu2 his3 lys1 ade2 ade8 & Henry and Silver (1996) \\
\hline PSY 902 & MATa/ $\alpha$ ura3-52/-leu2 $\Delta 1 /-$ his $3 \Delta 200 /$ trpl/+lys2/+ade2/+ade3/+ & this study \\
\hline PSY 992 & $\begin{array}{l}\text { MATa/ } \alpha \text { npl3::HIS3/npl3-17 ura3-52/-leu2-3/-his3/-trp1-1/+lys1-1/-ade2-1/- } \\
\text { ade8/-can1-100/- }\end{array}$ & this study \\
\hline PSY 1023 & MATa npl3-17 ura3-52 leu2-3 his3 Iys1-1 ade2-1 ade8 can1-100 & this study \\
\hline PSY 1096 & $\begin{array}{l}\text { MATa hmt1::HIS3 nup49::TRP ura3-52 leu2 lys }{ }^{-} \text {ade2 ade8 plus pUN 100-nup49-313- } \\
\text { LEU } 2\end{array}$ & this study \\
\hline PSY 1115 & MATa hmt1::HIS3 ura3 leu2 lys ${ }^{-}$ade2 ade3 plus pPS1347 & this study \\
\hline PSY 1116 & MATa hmt1:: HIS3 cbp80-1 ura3 leu2 lys ${ }^{-}$ade2 ade3 plus pPS1347 & this study \\
\hline PSY 1117 & MATa hmt1:: HIS3 cbp80-1 ura3 leu2 lys ${ }^{-}$ade2 ade3 plus pPS1351 & this study \\
\hline PSY 1118 & MAT $\alpha$ hmt1::HIS3 CBP80:LEU 2 ura3 leu2 his3 lys1 ade2 & this study \\
\hline PSY 1119 & MATa cbp80:: HIS3 ura3 leu2 his3 trpl ade2 & this study \\
\hline PSY 1120 & MAT $\alpha$ cbp80:: HIS3 ura3 leu2 lys1 ade2 ade8 & this study \\
\hline PSY 1121 & $\begin{array}{l}\text { MATa/ } \alpha \text { npl3::HIS3/NPL3 ura3-52/-leu2-3/-his3/-trp1-1/+lys1-1/-ade2-1/-ade8/- } \\
\text { can1-100/- }\end{array}$ & this study \\
\hline PSY 1122 & MATa hmt1::HIS3 ura3 leu2 his3 lys1 ade2 ade8 & Henry and Silver (1996) \\
\hline PSY 1123 & $\begin{array}{l}\text { MATa/ } \alpha \text { hrb1::HIS3/HRB1 ura3/-leu2/-his3/-trp1-1/+lys1/-ade2/-ade8/- } \\
\text { can1-100/- }\end{array}$ & this study \\
\hline PSY 1124 & MATa hrb1::HIS3 ura3 leu2 his3 trp1-1 lys1 ade2 ade8 can1-100 & this study \\
\hline PSY 1129 & MATa npl3:: HIS3 ura3-52 leu2-3 his3 trp1 lys1-1 ade2-1 ade8 can1-100 plus pPS1356 & this study \\
\hline
\end{tabular}


scribed (Henry and Silver 1996). Briefly, the $40-\mu l$ reaction contained $50 \mathrm{~mm}$ MOPS at pH 7.2, 2 mM EDTA, $300 \mathrm{~mm} \mathrm{NaCl}, 30$ $\mu \mathrm{M} S \mathrm{SAM}, 5.5 \mu \mathrm{Ci}$ [methyl ${ }^{3} \mathrm{H}$ ]-SAM (NEN Dupont, $80 \mathrm{Ci}$ / mmole), and $3 \mu \mathrm{g}$ of substrate protein. $\mathrm{N} \mathrm{pl3p-Myc,} \mathrm{HisHrplp,}$ and $\mathrm{Hrblp}$ were prepared from $\mathrm{E}$. coli, and the BSA control was purchased from Sigma. Reactions were initiated by the addition of $4 \mu \mathrm{g}$ of HisH mtlp or methylation assay buffer, and incubated at $30^{\circ} \mathrm{C}$ for $40 \mathrm{~min}$. Reactions were terminated by the addition of SDS-PAGE sample buffer and boiling for $5 \mathrm{~min}$ at $100^{\circ} \mathrm{C}$. Proteins were resolved by SDS-PAGE followed by Coomassie staining and fluorography.

Indirect immunofluorescence

Indirect immunofluorescence microscopy was performed exactly as described (Lee et al. 1996). Affinity purified rabbit anti$\mathrm{N} \mathrm{pl3p}$ (Bossie et al. 1992) was used at 1:1000, and 9E10 mouse monoclonal anti-Myc (Department of Molecular Biology, Princeton University, NJ) was used at 1:2. In situ hybridization to poly $(A)^{+}$RN A was performed exactly as described (Lee et al. 1996).

\section{CBP80 synthetic lethal screen}

To create the parental strain for the synthetic lethal screen, PSY 865 was mated with CH1305 (Kranz and Holm 1990), diploids were selected, tetrads were dissected, and one $\triangle$ HMT1::HIS3 ade2 ade3 spore was selected and transformed with pPS1347 to generate PSY 1115. pPS1347, a $2 \mu$ U RA 3 ADE3 HMT1 plasmid, was generated by subcloning of a $2.5-\mathrm{kb}$ BamHI fragment from pPS1307 (Henry and Silver 1996) into the BamH I site of pPS709 (Koepp et al. 1996).

Cells were mutagenized with EMS to 50\% killing. Approximately 53,000 colonies were screened. Three hundred and sixteen non-sectoring colonies were streaked on fresh YEPD medium plates. One candidate satisfied all the criteria (Henry and Silver 1996; Koepp et al. 1996) for synthetic lethality with $\triangle \mathrm{HMT1}$. A 4.2-kb Clal fragment containing one complete ORF in pRS316 (pPS1352) was the minimal region required to restore sectoring. Linkage of the synthetic lethality to CBP80 was checked by mating PSY 1118 with PSY 1116. The diploid was sporulated and tetrads analyzed for FOA sensitivity. PSY 1118 contains a LEU 2 marked copy of CBP80 generated by homologous recombination. To disrupt the CBP80 gene, a PCR strategy was performed (Baudin et al. 1993). To check synthetic lethality between $\triangle \mathrm{HMT} 1$ and $\triangle \mathrm{CBP} 80, \mathrm{PSY} 1119$ was outcrossed three times to the wild-type strain PSY609. The resulting $\triangle$ CBP80 strain, PSY 1120, was crossed to PSY 865, and tetrads were analyzed.

\section{Acknowledgments}

We gratefully acknowledge Adrian Krainer and Akila Mayeda for pET 9c-N PL3 and protocols for purification of recombinant protein from E. coli; Clarie Moore and Marco Kessler for pET 15b-HisH rp1; Patricia Chui for unpublished results; and Ed Hurt and F. Winston for strains. We also thank Michael Rosbash, Robert Kingston, and members of the Silver laboratory for critical reading of the manuscript and helpful comments and discussion. This work was funded by grants from the $\mathrm{N}$ ational Institutes of Health to P.A.S., The M edical Foundation Charles King Trust to M.S.L., a predoctoral fellowship from Sandoz Pharmaceuticals to E.C.S., and a N ational Science Foundation predoctoral fellowship to V.H.W. S.R.V. is on leave of absence from Faculdade de Ciencias Farmaceuticas de Araraquara-Uni- versidade Estadual Paulista and is a recipient of a postdoctoral fellowship from Fundacao de Amparo a Pesquisa do Estado de Sao Paulo (FAPESP).

The publication costs of this article were defrayed in part by payment of page charges. This article must therefore be hereby marked "advertisement" in accordance with 18 USC section 1734 solely to indicate this fact.

\section{References}

Adachi, Y. and M. Yanagida. 1989. Higher order chromosome structure is affected by cold-sensitive mutations in a Schizosaccharomyces pombe gene $\mathrm{CRM} 1^{+}$, which encodes a 115KD protein preferentially localized in the nucleus and its periphery. J. Cell Biol. 108: 1195-1207.

Baudin, A., O. Ozier-Kalogeropoulou, A. Denouel, F. Lacroute, and C. Cullin. 1993. A simple and efficient method of direct gene deletion in Saccharomyces cerevisiae. Nucleic Acids. Res. 21: 3329-3330.

Beyer, A.L., M.E. Christensen, B.W. Walker, and W.M. LeStourgeon. 1977. Identification and characterization of the packaging proteins of core $40 \mathrm{~S}$ hnRNP particles. Cell 11: 127138.

Birney, E., S. Kumar, and A.R. Krainer. 1993. Analysis of the RN A-recognition motif and RS and RGG domains: Conservation in metazoan pre-mRNA splicing factors. Nucleic ACids Res. 21: 5803-5816.

Boffa, L.C., J. Karn, G. Vidali, and V.G. Allfrey. 1977. Distribution of $N^{G}-N^{G}$-dimethylarginine in nuclear protein fractions. Biochem. Biophys. Res. Commun. 74: 969-976.

Bossie, M.A., C. DeHoratius, G. Barcelo, and P. Silver. 1992. A mutant nuclear protein with similarity to RN A binding proteins interferes with nuclear import in yeast. Mol. Biol. Cell 3: 875-893.

Calnan, B.J., B. Tidor, S. Biancalana, D. Hudson, and A.D. Frankel. 1991. Arginine-mediated RN A recognition: The arginine fork. Science 252: 1167-1171.

Cobianchi, F., C. Calvio, M. Stoppin, M. Buvoli, and S. Riva. 1993. Phosphorylation of human hnRN P protein Al abrogates in vitro strand annealing activity. Nucleic Acids Res. 21: 949-955.

Colot, H., F. Stutz, and M. Rosbash. 1996. The yeast splicing factor Mud13p is a commitment complex component and corresponds to CBP20, the small subunit of the nuclear cap binding complex. Genes \& Dev. 10: 1699-1708.

Doye, V., R. Wepf, and E.C. Hurt. 1994. A novel nuclear pore protein N up133p with distinct roles in poly(A)+RN A transport and nuclear pore distribution. EMBO J. 13: 6062-6075.

Dreyfuss, G., M .J. M atunis, S. Piñol-Roma, and C.G. Burd. 1993. hnRNP proteins and the biogenesis of mRNA. Annu. Rev. Biochem. 62: 289-321.

Fischer, U., M. Michael, R. Luhrmann, and G. Dreyfuss. 1996. Signal-mediated nuclear export pathways of proteins and RN As. Trends Cell Biol. 6: 290-293.

Flach, J., M. Bossie, J. Vogel, A. Corbett, T. Jinks, D.A. Willins, and P.A. Silver. 1994. A yeast RN A-binding protein shuttles between the nucleus and the cytoplasm. Mol. Cell Biol. 14: 8399-8407.

Fornerod, M., M. Ohno, M. Yoshida, and I.W. Mattaj. 1997. CRM 1 is an export receptor for leucinerich nuclear export signals. Cell 90: 1051-1060.

Gary, J.D., W.J. Lin, M.C. Yang, H.R. Herschman, and S. Clarke. 1996. The predominant protein-arginine methyltransferase from Saccharomyces cerevisiae. J. Biol. Chem. 271: 1258512594. 
Ghosh, S.K., W.K. Paik, and S. Kim. 1988. Purification and molecular identification of two protein methylases I from calf brain. Myelin basic protein and histone specific enzyme. J. Biol. Chem. 263: 19024-19033.

Gorlich, D., R. Kraft, S. Kostka, F. Vogel, E. Hartmann, R.A. Laskey, I.W. Mattaj, and E. Izaurral de. 1996. Importin provides a link between nuclear protein import and $U$ snRNA export. Cell 87: 21-32.

Hamm, J. and I.W. Mattaj. 1990. Monomethylated cap structures facilitate RNA export from the nucleus. Cell 63: 109118.

Henry, M., C.Z. Borland, M. Bossie, and P.A. Silver. 1996. Potential RNA binding proteins in Saccharomyces cerevisiae identified as suppressors of temperature-sensitive mutations in N PL3. Genetics 142: 103-115.

Henry, M.F. and P.A. Silver. 1996. A novel methyltransferase (H mtlp) modifies poly(A)+RN A binding proteins. Mol. Cell. Biol. 16: 3668-3678.

Izaurral de, E., J. Lewis, C. McGuigan, M. Jankowska, E. Darzynkiewicz, and I.W. Mattaj. 1994. A nuclear cap binding protein complex involved in premRNA splicing. Cell 78: 657-668.

Izaurralde, E., J. Lewis, C. Gamberi, A. Jarmolowski, C. McGuigan, and I.W. Mattaj. 1995. A cap-binding protein complex mediating U snRN A export. Nature 376: 709-712.

Izaurral de, E., A. Jarmolowski, C. Beisel, I.W. Mattaj, and G. Dreyfuss. 1997. A role for the M 9 transport signal of hnRN P A1 in mRN A nuclear export. J. Cell Biol. 137: 27-35.

Katsanis, N., M.L. Yaspo, and E.M. Fisher. 1997. Identification and mapping of a novel human gene, HRMT1L1, homologous to the rat protein arginine $\mathrm{N}$-methyltransferase 1 (PRM T 1) gene. Mammal. Genome 8: 526-529.

Kessler, M.M., M.F. Henry, E. Shen, J. Zhao, S. Gross, P.A. Silver, and C.L. Moore. 1997. Hrpl, a sequence-specific RN Abinding protein that shuttles between the nucleus and the cytoplasm, is required for mRN A 3 '-end formation in yeast. Genes \& Dev. 11: 2545-2556.

Kiledjian, M., C.G. Burd, D.S. Portman, and G. Dreyfuss. 1994. Structure and function of hnRN P proteins. In RNA-protein interactions: Frontiers in molecular biology (ed. K. Nagai and I.W. M attaj), pp. 127-149. IRL Press, Oxford, UK.

Koepp, D.M., D.H. Wong, A.H. Corbett, and P.A. Silver. 1996. Dynamic localization of the nuclear import receptor and its interactions with transport factors. J. Cell Biol. 133: 11631176.

Krainer, A.R., A. Mayeda, D. Kozak, and G. Binns. 1991. Functional expression of cloned human splicing factor SF2: Homology to RNA-binding proteins, U1 70K, and Drosophila splicing regulators. Cell 66: 383-394.

Kranz, J.E. and C. Holm. 1990. Cloning by function: An alternative approach for identifying yeast homologs from other organisms. Proc. Natl. Acad. Sci. 87: 6629-6633.

Lee, M.S. and P.A. Silver. 1997. RN A movement between the nucleus and the cytoplasm. Curr. O pin. 7: 212-219.

Lee, M.S., M. Henry, and P.A. Silver. 1996. A protein that shuttles between the nucleus and the cytoplasm is an important mediator of RNA export. Genes \& Dev. 10: 12331246.

Lewis, J.D., and E. Izaurral de. 1997. The role of the cap structure in RNA processing and nuclear export. Eur. J. Biochem. 247: 461-469.

Lewis, J.D., D. Gorlich, and I.W. Mattaj. 1996. A yeast capbinding protein complex (yCBC) acts as an early step in premRN A splicing. Nucleic Acids Res. 24: 3332-3336.

Lin, W.J., J.D. Gary, M.C. Yang, S. Clarke, and H.R. Herschman. 1996. The mammalian immediate-early TIS21 protein and the leukemia-associated BT G1 protein interact with a protein-arginine N-methyltransferase. J. Biol. Chem. 271: 1503415044.

Liu, Q. and G. Dreyfuss. 1995. In vivo and in vitro arginine methylation of RNA-binding proteins. Mol.Cell. Biol. 15: 2800-2808.

Mears, W.E. and S.A. Rice. 1996. The RGG box motif of the herpes simplex virus ICP27 protein mediates an RNA-binding activity and determines in vivo methylation. J. Virol. 70: 7445-7453.

Michael, W.M., M. Choi, and G. Dreyfuss. 1995. A nuclear export signal in hnRNP A1: A signal-mediated, temperaturedependent nuclear protein export pathway. Cell 83:415422.

N ajbauer, J., B.A. Johnson, A.L. Young, and D.W. Aswad. 1993. Peptides with sequences similar to glycine, arginine-rich motifs in proteins interacting with RNA are efficiently recognized by methyltransferase(s) modifying arginine in numerous proteins. J. Biol. Chem. 268: 10501-10509.

N eville, M., F. Stutz, L. Lee, L.I. Davis, and M. Rosbash. 1997. The importin-beta family member $\mathrm{Crm} 1 \mathrm{p}$ bridges the interaction between Rev and the nuclear pore complex during nuclear export. Curr. Biol. 7: 767-775.

Nigg, E. 1997. Nucleocytoplasmic transport: Signals, mechanisms and regulation. Nature 386: 779-787.

Nikawa, J., H. Nakano, and N. Ohi. 1996. Structural and functional conservation of human and yeast HCP1 genes which can suppress the growth defect of the Saccharomyces cerevisiae ire15 mutant. Gene 171: 107-111.

N onet, M., C. Scafe, J. Sexton, and R. Young. 1987. Eukaryotic RNA polymerase conditional mutant that rapidly ceases mRN A synthesis. Mol. Cell. Biol. 7: 1602-1611.

Ossareh-N azari, B., F. Bachelerie, and C. Dargemont. 1997. Evidence for a role of CRM 1 in signal-mediated nuclear protein export. Science 278: 141-144.

Philippsen, P., K. Kleine, R. Pohlmann, A. Dusterhoft, K. Hamberg, J.H. Hegemann, B. Obermaier, L.A. Urrestarazu, R. Aert, K. Albermann et al. 1997. The nucleotide sequence of Saccharomyces cerevisiae chromosome XIV and its evolutionary implications. Nature 387: 93-98.

Piñol-Roma, S. 1997. HnRN P proteins and the nuclear export of mRNA. Sem. Cell Dev. Biol. 8: 57-63.

Piñol-Roma, S. and G. Dreyfuss. 1992. Shuttling of premRN A binding proteins between nucleus and cytoplasm. Nature 355: 730-732.

- - - 1993. Cell cycle-regulated phosphorylation of the premRN A binding (heterogeneous nuclear ribonucleoprotein) C proteins. Mol. Cell. Biol. 13: 5762-5770.

Pintucci, G., N. Quarto, and D.B. Rifkin. 1996. Methylation of high molecular weight fibroblast growth factor-2 determines post-translational increases in molecular weight and affects its intracellular distribution. Mol. Biol. Cell 7: 1249-1258.

Rajpurohit, R., W.K. Paik, and S. Kim. 1994. Effect of enzymic methylation of heterogeneous ribonucleoprotein particle A 1 on its nucleic-acid binding and controlled proteolysis. Biochem. J. 304: 903-909.

Rawal, N., R. Rajpurohit, W.K. Paik, and S. Kim. 1994. Purification and characterization of S-adenosylmethionine protein arginine $\mathrm{N}$-methyltransferase from rat liver. Biochem J. 300: 483-489.

Russell, I.D., and D. Tollervey. 1992. N OP3 is an essential yeast protein which is required for pre-rRNA processing. J. Cell Biol. 119: 737-747.

Siebel, C.W. and C. Guthrie. 1996. The essential yeast RNA binding protein N pl $3 p$ is methylated. Proc. Natl. Acad. Sci. 93: 13641-13646. 
Singleton, D.R., S. Chen, M. Hitomi, C. Kumagai, and A.M. Tartakoff. 1995. A yeast protein that bidirectionally affects nucleocytoplasmic transport. J. Cell. Sci. 108: 265-272.

Soulard, M., D.V. Veronique, M.C. Siomi, S. Piñol-Roma, P. Codogno, C. Bauvy, M. Bellini, J.C. Lacroix, G. Monod, G. Dreyfuss, et al. 1993. hnRN P G: Sequence and characterization of a glycosylated RNA-binding protein. Nucleic Acids Res. 21: 4210-4217.

Stade, K., C.S. Ford, C. Guthrie, and K. Weis. 1997. Exportin 1 (Crm1p) is an essential nuclear export factor. Cell 90: 10411050.

Uemera, H. and Y. Jigami. 1992. GCR3 encodes an acidic protein that is required for expression of glycolytic genes in Saccharomyces cerevisiae. J. Bacteriol. 174: 5526-5532.

Ullman, K.S., M.A. Powers, and D.J. Forbes. 1997. N uclear export receptors: From importin to exportin. Cell 90: 967-970.

Visa, N ., A.T. Alzhanova-Ericsson, X. Sun, E. Kisel eva, B. Bjorkroth, T. Wurtz, and B. Daneholt. 1996a. A pre-mRN A-binding protein accompanies the RNA from the gene through the nuclear pores and into polysomes. Cell 84: 253-264.

Visa, N., E. Izaurral de, J. Ferreira, B. Daneholt, and I.W. M attaj. 1996b. A nuclear cap-binding complex binds Balbiani ring pre-mRN A cotranscriptionally and accompanies the ribonucleoprotein particle during nuclear export. J. Cell Biol. 133: 5-14.

Wilson, S.M., K.V. Datar, M.R. Paddy, J.R. Swedlow, and M. Swanson. 1994. Characterization of nuclear polyadenylated RNA-binding proteins in Saccharomyces cerevisiae. J. Cell Biol. 127: 1173-1184. 


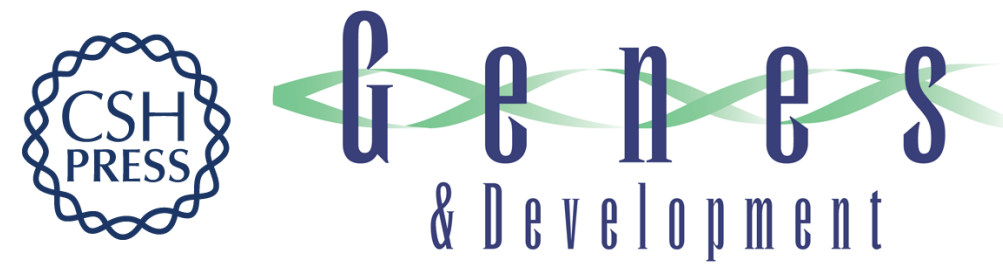

\section{Arginine methylation facilitates the nuclear export of hnRNP proteins}

Elisa C. Shen, Michael F. Henry, Valerie H. Weiss, et al.

Genes Dev. 1998, 12:

References This article cites 56 articles, 28 of which can be accessed free at: http://genesdev.cshlp.org/content/12/5/679.full.htmI\#ref-list-1

License

Email Alerting

Receive free email alerts when new articles cite this article - sign up in the box at the top Service right corner of the article or click here.

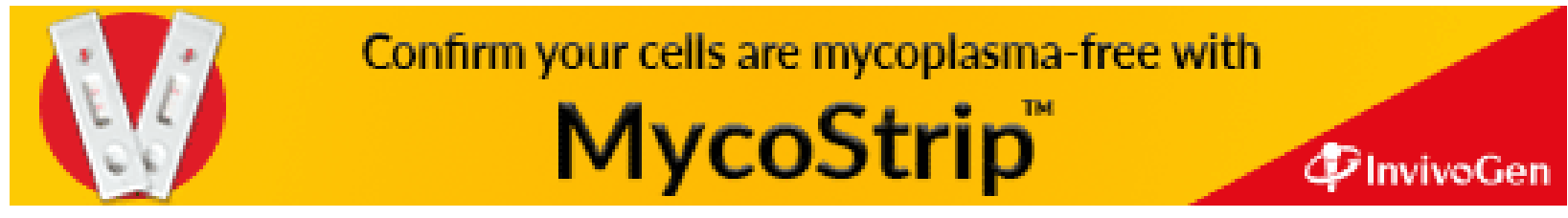

